\title{
Разработка методик фенотипирования диких видов картофеля
}

К.А. Колошина, К.А. Иванова, Е.Г. Комышев, М.А. Генаев, А.В. Кочетов, С.В. Герасимова

ФИЦ Институт ичитологии и генетики СО РАН, Новосибирск, Россия

*e-mail: kristina.koloshina@yandex.ru

Дикорастущие виды картофеля, сосредоточенные в мировой коллекции ВИР, являются ценным исходным материалом при создании высокопродуктивных и высококачественных сортов. Существующие данные о характеристиках разных образцов диких видов картофеля носят разнородный характер, что осложняет подбор материала и порождает необходимость дополнительных тестов для каждой конкретной задачи. Разработка и внедрение высокопроизводительных методов фенотипирования с использованием цифровой обработки изображений позволит привести данные о диких видах картофеля к единому формату и облегчит многие работы по отбору и характеристике материала в селекционных и исследовательских целях. Цель данной работы - изучение морфологических признаков и продуктивности ряда диких видов картофеля и разработка универсальных методов фенотипирования, наиболее полно и объективно характеризующих исследуемые образцы.

Была изучена коллекция диких видов картофеля, содержащая 38 образцов 14 видов (образцы любезно предоставлены д.б.н. Е.В. Рогозиной и д.б.н. С.Д. Киру, ВИР). Проведено размножение, первичная характеристика коллекции и введение образцов в культуру in vitro. Фенотипическая характеристика коллекции проводится несколькими способами при различных условиях культивирования: (1) характеристика различных показателей в условиях ростовой камеры, согласно рекомендациям ВИР; (2) характеристика диких видов в полевых условиях, по образцу, применяемому к сортам культурного картофеля; (3) характеристика показателей роста в культуре in vitro; (4) адаптация и применение авторских методов высокопроизводительного фенотипирования, позволяющих оценить различные морфологические параметры разных частей растения, в том числе ряд параметров клубнеобразования. Уникальный авторский метод [1], на основе которого создано бесплатное приложение, совместимое с OC Android (https://play. google.com/store/apps/details?id=org.wheatdb.seedcounter\&hl=ru), был адаптирован специально для диких форм картофеля с целью оценки клубнеобразования.

В результате интеграции данных, полученных разными методами, будет предложен оптимальный алгоритм фенотипирования диких видов картофеля

Благодарности: Работа выполнена при финансовой поддержке гранта РФФИ № 18-316-00068.

Список литературь

1. Komyshev E., Genaev M., Afonnikov D. (2017). Frontiers in Plant Science. 7:1990. 